Original paper

DOI: $10.5937 / Z e m B i l j 2102056 S$

\title{
Effect of inoculation with Bradyrhizobium and phosphate solubilizing bacteria on soybean seed yield and composition
}

Olivera Stajković-Srbinović*1, Djordje Kuzmanović ${ }^{1}$, Nataša Rasulić ${ }^{1}$, Magdalena Knežević ${ }^{1}$, Vladan Ugrenović $^{1}$, Aneta Buntić ${ }^{1}$, Dušica Delić ${ }^{1}$

${ }^{1}$ Institute of Soil Science, Teodora Drajzera 7, 11000 Belgrade, Serbia

*Corresponding author: Olivera Stajković-Srbinović, oliverastajkovic@yahoo.com

\begin{abstract}
In the field experiment, the effect of co-inoculation with Bradyrhizobium japonicum and two Pseudomonas sp. strains on seed yield and macronutrient uptake in soybean (Glycine max L.) was evaluated. The results showed that inoculation and co-inoculation of soybean seeds with B. japonicum and Pseudomonas sp. strains increased seed yield (from 65 up to 134\%), and uptake of N, P, K, Mg, and $\mathrm{Ca}\left(\mathrm{kg} \mathrm{ha}^{-1}\right.$ ) (from 65 to 167\%), compared to the control plants (uninoculated, non-fertilized plants). Phosphorous concentration $\left(\mathrm{mg} \mathrm{kg}^{-1}\right)$ was increased in inoculated and co-inoculated treatments (up to $15 \%$ ), compared to the control. The $\mathrm{N} \%$, as well as the concentrations of $\mathrm{K}$ and $\mathrm{Ca}$, did not differ significantly among treatments and control. Magnesium concentrations were increased in mineral fertilized and co-inoculated treatments. Uptake of all nutrients was in significant correlation with seed yield, while the concentration of $\mathrm{P}$ only correlated with seed yield. The results showed that coinoculation with bradyrhizobial and some phosphate solubilizing bacteria can increase the seed yield and uptake of $\mathrm{N}$ and $\mathrm{P}$ in soybean.
\end{abstract}

Keywords: inoculation, bradyrhizobia, Pseudomonas, nitrogen, phosphorous

\section{Introduction}

Soybean (Glycine max L.) is a very important leguminous plant used for human nutrition as well as fodder crop. Soybean seeds contain a high amount of proteins (40-42\%), oils (about 20\%), and minerals (calcium, zinc, iron) (Argaw, 2012). Soybean can form a symbiotic association with soil bacterium rhizobium, Bradyrhizobium japonicum, and fix atmospheric nitrogen $\left(\mathrm{N}_{2}\right)$. By establishing a symbiotic relationship and performing symbiotic $\mathrm{N}_{2}$ fixation, rhizobia improve the $\mathrm{N}$ content and soybean seed yield, thus reducing the need for nitrogen mineral fertilizer application in soybean cultivation. According to Unkovich and Pate (2000), the amounts of $\mathrm{N}_{2}$-fixed $\left(\mathrm{kg} \mathrm{ha}^{-1}\right)$ by soybean have been up to $450 \mathrm{~kg} \mathrm{~N} \mathrm{ha}{ }^{-1}$. Besides $\mathrm{N}$, phosphorous supply is very important for soybean since it is required for nodule development and functioning (Sa and Israel, 1991). However, the availability of P to plants in the soil is usually very low, mainly because P exists in the soil as insoluble inorganic and/or organic phosphorus (Walpola and Yoon, 2012). This depends on the $\mathrm{pH}$ of the soil where $\mathrm{P}$ can be immobilized in calcium phosphate $\left(\mathrm{Ca}_{3}\left(\mathrm{PO}_{4}\right)_{2}\right)$ (in alkaline or neutral soils) or aluminum (AlPO) and ferrous phosphate (FePO) (in acidic soils) (Kalayu, 2019). The conversion of these insoluble P forms into 
soluble forms available for plant growth can be achieved using P solubilizing bacteria. In alkaline soil, these bacteria can dissolve the insoluble soil phosphates by producing organic acids that chelate the cations and compete with the phosphate for adsorption sites in the soil resulting in $\mathrm{P}$ solubilization. On the other hand, insoluble organic $\mathrm{P}$ can become bioavailable by mineralization using these $\mathrm{P}$ solubilizing bacteria. Several organic acids can be released by $\mathrm{P}$ solubilizing bacteria and their solubilization efficiency depends on the strength and nature of the acids (Kalayu, 2019; Alori et al., 2017). These soil bacteria could be useful in soybean production improvement by increasing P content in the soil and enhancing nodulation and $\mathrm{N}$ fixation. Many of them belong to the genera such as Pseudomonas, Bacillus, Azotobacter, Paenibacillus, Serratia, Burkholderia, Enterobacter, Erwinia, Kushneria, Rhodococcus, Salmonella, Sinomonas, Thiobacillus (Alori et al., 2017). The inoculation of soil or crop with $\mathrm{P}$ solubilizing/mineralizing bacteria ( $\mathrm{P}$ biofertilizers) is an eco-friendly strategy for reduction application of chemical fertilizers that have a negative impact on the environment to improve $\mathrm{P}$ absorption by plants (Alori et al., 2012; Babalola and Glick, 2012). In addition, some studies indicated that rhizobia, besides $\mathrm{N}_{2}$ fixation, may influence certain macro and micronutrient contents in leguminous plants and soil, such as various strains from Rhizobium and Bradyrhizobium (Alori et al., 2017; Ndakidemi et al., 2011; Bambara and Ndakidemi, 2010). Rhizobial strains enhanced the uptake of many macro and micronutrients in peanut nodules and seeds (Howell, 1987), soybean (Tairo and Ndakidemi, 2014 a,b), and common bean plants (Makoi et al., 2013; Ndakidemi et al., 2011).

There are some researches regarding the co-inoculation of legume plants with a consortium of rhizobial and non-rhizobial bacteria (Marinković et al. 2018; Stajković et al., 2011; Argaw, 2012). Kumawat et al. (2019) used Pseudomonas aeruginosa (LSE-2) nodule endophyte with Bradyrhizobium sp. (LSBR-3) as biofertilizer of soybean. Argaw (2012) also studied the effect of co-inoculation of Bradyrhizobium japonicum (TAL-378 and TAL-379) and P-solubilizing bacteria Pseudomonas spp. on nodulation, yield, and yield components of soybean. Co-inoculaton with Bradyrhizobium japonicum and Azotobacter chroococcum had better effect on soybean yield compared to single inoculation with Bradyrhizobium japonicum (Marinković et al., 2018).

Therefore, the aim of this research was to determine if the co-inoculation of soybean with Bradyrhizobium japonicum and two Pseudomonas P-solubilizing strains can additionally improve seed yield and macro nutrient uptake, compared to rhizobial inoculation alone.

\section{Materials and methods Soil and experiment design}

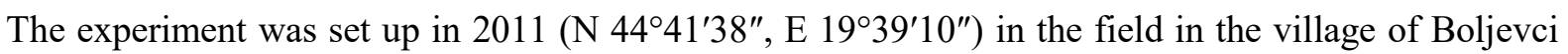
(near Belgrade, Serbia), on Chernozem soil (FAO, 1998) with the following chemical characteristics (Table 1). In 2011., the average monthly temperatures during the vegetation period (from March to 
October) were $12.9^{\circ} \mathrm{C}$ with a maximum in June of $24.8^{\circ} \mathrm{C}$, while the total amount of rainfall was 541.1 $\mathrm{mm}$. In the past 10 years, legumes have not been grown in the experimental field.

Strains Bradyrhizobium japonicum 542, as well as Pseudomonas sp. L2Cr and LG from the Collection of the Institute of Soil Science were used for the inoculation or co-inoculation of soybean (variety Biser, maturity group 0). Pseudomonas strains were previously characterized and identified by Stajković et al. (2009) and Knežević et al. (2021). Pseudomonas strains were cultivated for $24 \mathrm{~h}$ in King B medium while Bradyrhizobium strains were grown in yeast mannitol broth (YMB) for 5 days. The culture of $40 \mathrm{~mL}$ of each strain was mixed with $100 \mathrm{~g}$ of sterile ground peat and after a 15-day incubation period, single inoculums consisting of approximately $10^{9}$ bacteria per $\mathrm{g}$ peat were obtained (Somesegaran and Hoben, 1994). The trial was designed with 3 inoculated treatments B. japonicum 542, B. japonicum 542 + Pseudomonas LG (Bradyrhizobium + P1), B. japonicum 542 + Pseudomonas $\mathrm{L} 2 \mathrm{Cr}$ (Bradyrhizobium + P1), treatment with mineral NPK fertilizer $\left(\mathrm{N} 60 \mathrm{~kg} \mathrm{ha}^{-1}, \mathrm{P} 100 \mathrm{~kg} \mathrm{ha}^{-1}\right.$ and K $\left.100 \mathrm{~kg} \mathrm{ha}^{-1} ; \mathrm{N} \varnothing\right)$, and control without mineral $\mathrm{N}$ fertilizer and inoculation (Ø). In the co-inoculation treatment, the ratio of Bradyrhizobium and Pseudomonas inoculum was 1:1. The experiment was laid out in a completely randomized design in three replications. Each plot was planted in 6 rows of $2 \mathrm{~m}$ length with an inter-row spacing of $50 \mathrm{~cm}$, with a final number of 40 plants per row. The seeds were sown during the first week of May 2011, and no mineral fertilizers or pesticides were used before sowing and during the vegetation period. Soybean seeds were hand-harvested at full maturity in the last week of August.

\section{Soil and seed samples analyses}

For mineral nutrient analysis, the seeds were dried at $65^{\circ} \mathrm{C}$ for $72 \mathrm{~h}$, ground in a mill to pass through a 1-mm mesh. The concentrations of N, C, and S were analyzed using an elemental CNS analyzer, Vario model EL III (ElementarAnalysensysteme GmbH, Hanua, Germany). To determine K, P, Mg, and Ca in the seed, the ground material was burned to ash at $550^{\circ} \mathrm{C}$ in a muffle furnace, and acid digestion with $\mathrm{HNO}_{3}$ and $\mathrm{HCl}$ was performed (AOAC, 1990). Element concentrations were analyzed using a Thermo iCAP 6300 Duo (ICP-OES).

Soil $\mathrm{pH}$ was determined using a glass electrode $\mathrm{pH}$ meter in $1 \mathrm{M} \mathrm{KCl}$ and in $\mathrm{H}_{2} \mathrm{O}$ (soil: $\mathrm{KCl}$ or $\mathrm{H}_{2} \mathrm{O}$ 1:2.5 ratio). Available $\mathrm{P}$ and $\mathrm{K}$ in soil were determined by the AL-method of Egner-Riehm (Egnér et al., 1960). Soil $\mathrm{Ca}$ and $\mathrm{Mg}$ were extracted with ammonium acetate and determined using a dual atomic adsorption spectrophotometer SensAA (Dandenong, Australia). Organic C and N in the soil were determined using an elementary CNS analyser, Vario model EL III (Hanau, Germany). 
Original paper

\section{Statistical analysis}

The effect of the treatments was evaluated using analysis of variance (SPSS 16.0 program, 2007) and significant differences between means were tested by Duncan's multiple range test.

\section{Results}

The soil of the experimental field had a neutral reaction and it was well supplied with $\mathrm{N}, \mathrm{P}$, and $\mathrm{K}$ (Table 1). The soil type was Chernozem, and according to the soil texture, it was clay loam (Table 2).

Table 1. Soil chemical properties

\begin{tabular}{cccccc}
\hline $\mathrm{pH}$ & $\mathrm{pH}$ & $\mathrm{P}_{2} \mathrm{O}_{5}$ & $\mathrm{~K}_{2} \mathrm{O}$ & $\mathrm{N}_{\text {tot }}$ & $\mathrm{C}_{\text {org }}$ \\
$\mathrm{H}_{2} \mathrm{O}$ & $\mathrm{KCl}$ & $\mathrm{mg} \mathrm{100} \mathrm{g}^{-1}$ & $\mathrm{mg} \mathrm{100} \mathrm{g}^{-1}$ & $\%$ & $\%$ \\
& & 21.81 & 33.59 & 0.27 & 3.7 \\
\hline 7.00 & 6.65 & & & $\%$ & 0 \\
\hline
\end{tabular}

Table 2. Soil texture

\begin{tabular}{ccccccc}
\hline $\begin{array}{c}\text { Coarse sand \% } \\
>0.2 \mathrm{~mm}\end{array}$ & $\begin{array}{c}\text { Fine sand \% } \\
0.2-0.02 \\
\mathrm{~mm}\end{array}$ & $\begin{array}{c}\text { Silt \% } \\
0.02-0.002 \mathrm{~mm}\end{array}$ & $\begin{array}{c}\text { Clay \% } \\
<0.002 \\
\mathrm{~mm}\end{array}$ & $\begin{array}{c}\text { Total send \% } \\
>0.02 \mathrm{~mm}\end{array}$ & $\begin{array}{c}\text { Silt + clay \% } \\
<0.02 \mathrm{~mm}\end{array}$ & $\begin{array}{c}\text { Textural } \\
\text { classis }\end{array}$ \\
\hline 0.5 & 28.2 & 32.2 & 39.1 & 28.7 & 71.3 & Clay loam \\
\hline
\end{tabular}

Soybean seed yield in all inoculated treatments was increased compared to the control, indicating symbiotic efficiency of the strains (Table 3). The highest yield was obtained in the treatment with NPK mineral fertilizer application and the treatment with co-inoculation with B. japonicum 542 and Pseudomonas LG. The co-inoculation with B. japonicum 542 and Pseudomonas $\mathrm{L} 2 \mathrm{Cr}$ realised lower yield than single inoculation with B. japonicum 542, but without statistical significance. There were no significant differences in $\mathrm{N}$ percentages (N\%) among treatments, which is probably due to very small yield in the control plants compared to inoculated treatments and dilution effect in higher yielded treatments.

Table 3. Seed yield and macronutrient concentrations of soybean plants inoculated with Bradyrhizobium and Pseudomonas.

\begin{tabular}{ccccccc}
\hline \multirow{2}{*}{ Treatment } & Grain yield & $\mathrm{N}$ & $\mathrm{P}$ & $\mathrm{K}$ & $\mathrm{Ca}$ & $\mathrm{Mg}$ \\
\cline { 2 - 7 } & $\mathrm{t} \mathrm{ha}^{-1}$ & $\%$ & $\mathrm{~g} \mathrm{~kg}^{-1}$ & $\mathrm{~g} \mathrm{~kg}^{-1}$ & $\mathrm{~g} \mathrm{~kg}^{-1}$ & $\mathrm{~g} \mathrm{~kg}^{-1}$ \\
\hline Bradyrhizobium $^{*}$ & $3.28 \mathrm{~b}$ & $6.46 \mathrm{a}$ & $5.36 \mathrm{a}$ & $15.70 \mathrm{a}$ & $3.56 \mathrm{a}$ & $2.54 \mathrm{c}$ \\
Bradyrhizobium $+\mathrm{P} 1$ & $4.19 \mathrm{a}$ & $6.28 \mathrm{a}$ & $5.36 \mathrm{a}$ & $15.84 \mathrm{a}$ & $3.76 \mathrm{a}$ & $2.70 \mathrm{~b}$ \\
Bradyrhizobium $+\mathrm{P} 2$ & $2.88 \mathrm{~b}$ & $6.51 \mathrm{a}$ & $4.86 \mathrm{~b}$ & $15.95 \mathrm{a}$ & $3.88 \mathrm{a}$ & $2.64 \mathrm{bc}$ \\
$\varnothing$ & $1.79 \mathrm{c}$ & $6.37 \mathrm{a}$ & $4.70 \mathrm{~b}$ & $15.62 \mathrm{a}$ & $3.49 \mathrm{a}$ & $2.54 \mathrm{c}$ \\
$\mathrm{N} \varnothing$ & $4.35 \mathrm{a}$ & $6.44 \mathrm{~ns}$ & $5.28 \mathrm{a}$ & $15.92 \mathrm{~ns}$ & $3.32 \mathrm{~ns}$ & $2.91 \mathrm{a}$ \\
\hline
\end{tabular}

Ø- control (no inoculation and no fertilization); NØ- treatment with NPK fertilization and without inoculation; ns- statistically not significant; values followed by the same letter in a column are not significantly different (Duncan test, P< 0.05); *- B. japonicum 542; P1- Pseudomonas sp. LG; P2- Pseudomonas sp. L2Cr. 
Original paper DOI: $10.5937 / Z e m B i l j 2102056 S$

However, the total $\mathrm{N}$ content $\left(\mathrm{kg} \mathrm{ha}^{-1}\right)$ in all inoculated treatments was increased (Table 4$)$. The concentration of $\mathrm{P}$ in soybean seeds was increased in all treatments compared to the control except in the co-inoculation with B. japonicum 542 and Pseudomonas L2Cr (Table 4). There were no differences between inoculation and co-inoculation with LG strain. The increase in P concentration was $14 \%$ for inoculation and co-inoculation with the LG strain, and 3\% for co-inoculation with the L2Cr strain, compared to the control. Total P content $\left(\mathrm{kg} \mathrm{ha}^{-1}\right)$ was increased in all treatments compared to control, with the highest values measured in co-inoculation with B. japonicum 542 and Pseudomonas LG and treatment with mineral fertilizer application (Table 4). The highest percentage increase in P uptake among treatments was in the treatment Bradyrhizobium + P1 compared to the control and was approximately $167 \%$ (Table 5).

Table 4. Macronutrients uptake in soybean seeds inoculated with Bradyrhizobium and Pseudomonas strains.

\begin{tabular}{cccccc}
\hline \multirow{2}{*}{ Treatment } & $\mathrm{N}$ & $\mathrm{P}$ & $\mathrm{K}$ & $\mathrm{Ca}$ & $\mathrm{Mg}$ \\
\cline { 2 - 6 } & \multicolumn{5}{c}{$\mathrm{kg} \mathrm{ha}^{-1}$} \\
\hline Bradyrhizobium $^{*}$ & $211.89 \mathrm{ab}$ & $17.58 \mathrm{~b}$ & $51.50 \mathrm{~b}$ & $11.68 \mathrm{bc}$ & $8.33 \mathrm{bc}$ \\
Bradyrhizobium + P1 & $262.92 \mathrm{a}$ & $22.44 \mathrm{a}$ & $66.32 \mathrm{a}$ & $15.74 \mathrm{a}$ & $11.30 \mathrm{ab}$ \\
Bradyrhizobium + P2 & $187.49 \mathrm{~b}$ & $14.00 \mathrm{~b}$ & $45.94 \mathrm{~b}$ & $11.17 \mathrm{c}$ & $7.60 \mathrm{c}$ \\
$\varnothing$ & $113.81 \mathrm{c}$ & $8.40 \mathrm{c}$ & $27.91 \mathrm{c}$ & $6.23 \mathrm{~d}$ & $4.54 \mathrm{~d}$ \\
$\mathrm{~N} \varnothing$ & $279.93 \mathrm{a}$ & $22.95 \mathrm{a}$ & $69.20 \mathrm{a}$ & $14.43 \mathrm{ab}$ & $12.65 \mathrm{a}$ \\
\hline
\end{tabular}

Ø- control (no inoculation and no fertilization); NØ- treatment with NPK fertilization and without inoculation; ns- statistically not significant; values followed by the same letter in a column are not significantly different (Duncan test, $P<0.05$ ); *- B. japonicum 542; P1-Pseudomonas sp. LG; P2- Pseudomonas sp. L2Cr.

Table 5. Percentage of increase in seed yield and macronutrient uptake of soybean inoculated with Bradyrhizobium and Pseudomonas strains compared to control.

\begin{tabular}{ccccccc}
\hline Treatment & $\begin{array}{c}\text { Grain } \\
\text { yield }\end{array}$ & $\mathrm{N}$ & $\mathrm{P}$ & $\mathrm{K}$ & $\mathrm{Ca}$ & $\mathrm{Mg}$ \\
\hline Bradyrhizobium $^{*}$ & 84 & 87 & 109 & 85 & 87 & 84 \\
Bradyrhizobium + P1 & 134 & 131 & 167 & 138 & 152 & 149 \\
Bradyrhizobium + P2 & 61 & 65 & 67 & 65 & 79 & 68 \\
$\varnothing$ & 0 & 0 & 0 & 0 & 0 & 0 \\
$\mathrm{~N} \varnothing$ & 143 & 146 & 173 & 148 & 131 & 179 \\
\hline
\end{tabular}

$\varnothing$ - control (no inoculation and no fertilization); NØ- treatment with NPK fertilization and without inoculation;

*- B. japonicum 542; P1-Pseudomonas sp. LG; P2-Pseudomonas sp. L2Cr.

Concentrations of $\mathrm{K}$ and $\mathrm{Ca}$ did not differ among treatments, while $\mathrm{Mg}$ concentrations were increased only in mineral fertilizer and Bradyrhizobium + P1 co-inoculation treatments, compared to the control (Table 3). Total uptake of $\mathrm{K}, \mathrm{Ca}$, and $\mathrm{Mg}$ was increased in all treatments and there were no differences between mineral fertilizer and Bradyrhizobium + P1 co-inoculation treatment (Table 4).

There were no negative correlations between any of the soybean seed parameters (yield, macronutrient concentrations) and total macronutrient content (Table 6). Table 6 shows only significant 
correlation values. Positive and very significant correlations were observed between grain yield and all macronutrients uptake, as well as significant correlations between $\mathrm{P}$ concentration and $\mathrm{P}$ uptake.

Table 6. Significant correlations among soybean seed parameters.

\begin{tabular}{|c|c|c|c|c|c|c|c|c|c|c|c|}
\hline & Yield & $\mathrm{N}$ & $\mathrm{P}$ & K & $\mathrm{Ca}$ & $\mathrm{Mg}$ & $\mathrm{N}^{\#}$ & $\mathrm{P}^{\#}$ & $\mathrm{~K}^{\#}$ & $\mathrm{Ca}^{\#}$ & $\mathrm{Mg}^{\#}$ \\
\hline $\mathrm{N}^{\#}$ & $.999^{* *}$ & & & & & & & & & & \\
\hline $\mathrm{P}^{\#}$ & $.997^{\text {** }}$ & & $.900^{*}$ & & & & $.994^{* *}$ & & & & \\
\hline $\mathrm{K}^{\#}$ & $1.000^{* * *}$ & & & & & & $.999^{* * *}$ & $.995^{* *}$ & & & \\
\hline $\mathrm{Ca}^{\#}$ & $.976^{* *}$ & & & & & & $.972^{* *}$ & $.971^{* *}$ & $.977^{* * *}$ & & \\
\hline $\mathrm{Mg}^{\#}$ & $.991^{* *}$ & & & & & & $.991^{* *}$ & $.982^{* *}$ & $.992^{* *}$ & $.949^{*}$ & \\
\hline
\end{tabular}

${ }^{*} p<0.05$ significant correlation; $* * p<0.01$ very significant correlation; ${ }^{*}$-uptake.

\section{Discussion}

The inoculation of soybean with rhizobacteria produced a wide range of effects in plant development (Marinković et al., 2018). Simultaneous inoculation with rhizobia and some plant-growth promoting rhizobacteria (PGPR) can increase growth and yield, compared to rhizobium inoculation alone in leguminous plants including soybean (Hungria et al., 2015; Stajković et al., 2009; Itzigsohn et al., 1993). However, published results mainly showed that co-inoculation of soybean with Bradyrhizobium and other PGPR could substantially increase the number of nodules, nodule biomass, root biomass, and shoot biomass in soybean, but no significant differences in shoot $\mathrm{N}$ content and grain were observed (Zeffa et al., 2020). In addition, the co-inoculation effects were more evident in pot experiments than in the field (Zeffa et al., 2020). Due to this, the effects of soybean co-inoculation with bradyrhizobia and Pseudomonads on soybean seed yield and nutrient content in field conditions were tested in this study.

The seed yield increased in the co-inoculation treatment Bradyrhizobium $+\mathrm{P} 1$ by $27 \%$ compared to a single inoculation with Bradyrhizobium. Compared to the control, this increase was as much as 2.3 and 1.64 times higher for the Bradyrhizobium + P1 and Bradyrhizobium + P2 treatments, respectively. An increase in seed yield with co-inoculation with B. japonicum and P solubilizing Pseudomonas sp. was previously reported by Argaw, 2012, together with an increase in $\mathrm{N} \%$ and $\mathrm{P}$ uptake $\left(\mathrm{kg} \mathrm{ha}^{-1}\right) . B$. japonicum TAL 378 and Pseudomonas spp. treatment achieved significantly higher seed yield per hectare than the negative control among the tested co-inoculation treatments and amounted to $36.3 \%$ (Argaw, 2012), which was less than co-inoculation treatments in this study. Marinković et al. (2018) also observed an increase in seed yield with co-inoculation treatment with B. japonicum and Azotobacter chroococcum about $46 \%$ compared to the control. These authors reported that inoculation/co-inoculation with highly effective PGPR could activate the microbial process in the crop rhizosphere and potentiate better plant growth by favoring rhizobia proliferation. The change in the 
number of PGPR in the crop rhizosphere was not monitored in this study, but the establishment of a significant number of these bacteria may lead to an increase in biomass and grain production at a later stage of soybean development (Bashan et al., 2004; Marinković et al., 2018). In addition, an increase in the grain yield might be the result of the microorganisms involved in $\mathrm{P}$ solubilization. These bacteria can enhance plant growth by increasing the efficiency of biological fixation, enhancing the bioavailability of trace elements, and by the production of plant growth- promoting substances (Argaw, 2012).

In this research, N\% was not increased compared to the control in any inoculated treatments, probably due to very low yield in the control treatment and nitrogen dilution in high yield obtained by inoculation (Jarrell and Beverly, 1981; Timmer, 1991). However, the total $\mathrm{N}$ uptake was increased significantly. Compared to the control, P concentration increased up to the same level in inoculation with Bradyrhizobium and in co-inoculation with Pseudomonas LG, while strain L2Cr had no influence on $\mathrm{P}$ concentration. Total $\mathrm{P}$ uptake was increased in all treatments compared to the control. The treatment of Bradyrhizobium + P1 in comparison with the treatment with mineral NPK fertilizer achieved similar concentrations of $\mathrm{N}$ and $\mathrm{P}$ in soybean seed and whose differences were not significant. This could be due to the fact that this co-inoculation provided similar $\mathrm{N}$ and $\mathrm{P}$ nutrients as the chemical fertilizer (Argaw, 2012). Phosphorus uptake increased in co-inoculation mainly as a result of $\mathrm{P}$ solubilizing microorganisms, which in addition to solubilizing $\mathrm{P}$, produce a necessary phytohormone, indole-3-acetic acid, thereby enhancing root growth and increasing nutrient uptake (Argaw, 2012). In addition, Pseudomonas LG strain showed good results for the total content of $\mathrm{N}$ and $\mathrm{P}$ in the biomass of common bean in co-inoculation with the Rhizobium phaseoli 123 in comparison with single inoculation with rhizobium and control in a previous study by Stajković et al. (2011). Increasing the availability of other macroelements $(\mathrm{K}, \mathrm{Ca} \mathrm{Mg})$, as well as $\mathrm{N}$ and $\mathrm{P}$ could be associated with the production of siderophores, IAA, and/or ammonia production. These abilities have been previously confirmed for the strain LG (Stajković et al., 2011).

Previously, the co-inoculation of soybean seeds with B. japonicum and P. fluorescens in conjunction with either $75 \%$ or $100 \%$ of the recommended dose of nitrogenous and phosphatic fertilizers significantly increased different plant parameters, including grain yield, $\mathrm{N}$ and $\mathrm{P}$ uptake in soybean (Pawar et al., 2018). Co-inoculation of Bradyrhizobium and P. Pseudomonas strain 54RB with the $\mathrm{P}_{2} \mathrm{O}_{5}$ treatment resulted in an increased grain yield of $38 \%$ in pot experiments and $12 \%$ in the field experiment, compared to the $\mathrm{P}_{2} \mathrm{O}_{5}$ treatment alone (Azfal et al., 2010). In the same research, maximum seed $\mathrm{P} \%, \mathrm{~N} \%$, and protein\% were recorded by Bradyrhizobium-Pseudomonas $-\mathrm{P}_{2} \mathrm{O}_{5}$ treatment. Production of plant growth regulators, $\mathrm{P}$ solubilization activity, and increased colonization in the rhizosphere suggest the mechanism of action of co-inoculated $\mathrm{N}$-fixing and P-solubilizing microorganisms (Azfal et al., 2010). 
Original paper

\section{Conclusions}

All treatments (inoculation and co-inoculations) had a positive effect on soybean seed yield, while the highest increase was obtained by co-inoculation with B. japonicum 542 and Pseudomonas L2Cr. The best effect on macronutrients uptake was also achieved by co-inoculation treatment with Pseudomonas L2Cr. The absence of significant differences between co-inoculation treatment with Pseudomonas $\mathrm{L} 2 \mathrm{Cr}$ and treatment with mineral NPK fertilizer on the uptake of N, P, Ca Mg, and K give the possibility of applying microbial instead of mineral fertilizer. Replacement of mineral nitrogen fertilizers with microbial fertilizers represents a well-justified ecologically acceptable perspective in the production of soybeans and high-quality organic food.

Acknowledgment. This work was supported by the Ministry of Education, Science and Technological Development of the Republic of Serbia (Contracts No. 451-03-9/2021-14/200011).

\section{References}

Afzal A, Bano A, Fatima M. 2010. Higher soybean yield by inoculation with N-fixing and P solubilizing bacteria. Agronomy for Sustainable Development 30:487-495.

Alori ET, Glick BR, Babalola OO. 2017. Microbial phosphorus solubilization and its potential for use in sustainable agriculture. Frontiers in microbiology, 8, 971, doi: 10.3389/fmicb.2017.00971.

Alori E, Fawole O, Afolayan A. 2012. Characterization of arbuscular mycorrhizal spores isolated from Southern Guinea Savanna of Nigeria. Journal of Agricultural Science 4:13-19. doi: $10.5539 /$ jas.v4n7p13

AOAC 1990. Official methods of analysis of the Association of Official Analytical Chemists. 15th edition. Washington, DC, Association of Official Analytical Chemists.

Argaw A. 2012. Evaluation of co-inoculation of Bradyrhizobium japonicum and Phosphate solubilizing Pseudomonas spp. effect on soybean (Glycine max L. Merr.) in Assossa Area. Journal of Agricultural Science and Technology 14(1):213-224.

Babalola OO, Glick BR. 2012. The use of microbial inoculants in African agriculture: current practice and future prospects. Journal of Food, Agriculture and Environment 10:540-549.

Bambara S, Ndakidemi PA. 2010. Changes in selected soil chemical properties in the rhizosphere of Phaseolus vulgaris L. supplied with Rhizobium inoculants, molybdenum and lime. Scientific Research and Essays 5:679-684.

Bashan Y, Holguin G, De-Bashan LE. 2004. Azospirillum-plant relationships: physiological, molecular, agricultural and environmental advances (1997-2003). Canadian Journal of Microbiology 50:521577. 
Egnér H, Riehm H, Domingo WR, 1960. Untersuchungen über die chemische Bodenanalyse als Grundlage für die Beurteilung des Nährstoffzustandes der Böden. II. Chemische Extraktionsmethoden zur Phosphor- und Kaliumbestimmung. Kungliga Lantbrukshögskolans Annaler 26, 199-215.

Howell RK. 1987. Rhizobium induced mineral uptake in peanut tissues. Journal of Plant Nutrition 6:1297-1305.

Hungria M, Nogueira MA, Araujo RS. 2015. Soybean Seed Co-Inoculation with Bradyrhizobium spp. and Azospirillum brasilense: A New Biotechnological Tool to Improve Yield and Sustainability. American Journal of Plant Sciences 6:811-817.

Jarrell WM, Beverly RB. 1981. The dilution effect in plant nutrition studies. Advances in Agronomy 34:197-224.

Itzigsohn R, Kapulnik Y, Okon Y, Dovrat A. 1993. Physiological and Morphological Aspects of Interactions between Rhizobium meliloti and Alfalfa (Medicago sativa) in Association with Azospirillum brasilense. Canadian Journal of Microbiology 39:610-615.

Kalayu G. 2019. Phosphate solubilizing microorganisms: promising approach as biofertilizers. International Journal of Agronomy, 2019, 4917256.

Knežević M, Berić T, Buntić A, Delić D, Nikolić I, Stanković S, Stajković-Srbinović O. 2021. Potential of root nodule nonrhizobial endophytic bacteria for growth promotion of Lotus corniculatus L. and Dactylis glomerata L. Journal of Applied Microbiology, doi:10.1111/jam.15152.

Kumawat KC, Sharma P, Sirari A, SinghI, Gill BS, Singh U, Saharan K. 2019. Synergism of Pseudomonas aeruginosa (LSE-2) nodule endophyte with Bradyrhizobium sp. (LSBR-3) for improving plant growth, nutrient acquisition and soil health in soybean. World Journal of Microbiology and Biotechnology 35(3):1-17.

Makoi JH, Bambara S, Ndakidemi PA. 2013. Rhizobium inoculation and the supply of molybdenum and lime affect the uptake of macroelements in common bean (P. vulgaris L.) plants. Australian Journal of Crop Science 7:784-793.

Marinković J, Bjelić D, Tintor B, Miladinović J, Đukic V, Đorđevic V. 2018. Effects of soybean coinoculation with plant growth promoting rhizobacteria in field trial. Romanian Biotechnological Letters 23(2):13401.

Ndakidemi PA, Bambara S, Makoi JHJR. 2011. Micronutrient uptake in common bean (Phaseolus vulgaris L.) as affected by Rhizobium inoculation, and the supply of molybdenum and lime. Plant OMICS 4:40-52.

Pawar PU, Kumbhar CT, Patil VS, Khot GG. 2018. Effect of co-inoculation of Bradyrhizobium japonicum and Pseudomonas fluorescens on growth, yield and nutrient uptake in soybean [Glycine $\max ($ L.) Merrill]. Crop Research 53 (1\&2):57-62. 
Sa TM, Israel, DW. 1991. Energy status and functioning of phosphorus-deficient soybean nodules. Plant Physiology 97:928-935. doi: 10.1104/PP.97.3.928

Somasegaran P, Hoben HJ. 1994. Handbook for rhizobia. Methods in legume Rhizobium technology. Springer, New York.

Stajković O, De Meyer S, Miličić B, Willems A, Delić D. 2009. Isolation and characterization of endophytic non-rhizobial bacteria from root nodules of alfalfa (Medicago sativa L.). Botanica Serbica 33, 107-114.

Stajković O, Delić D, Jošić D, Kuzmanović Đ, Rasulić N, Knežević-Vukčević J. 2011. Improvement of Common Bean Growth by Co-Inoculation with Rhizobium and Plant Growth-Promoting Bacteria. Romanian Biotechnological Letter, 16; 5919-5926.

Timmer VR. 1991. Interpretation of seedling analysis and visual symptoms. In: Van den Driessche R (Ed). Mineral Nutrition of Conifer Seedlings. CRC Press, Florida pp 113-134.

Tairo EV, Ndakidemi PA. 2014b. Micronutrients uptake in soybean (Glycine max L.) as affected by Bradyrhizobium japonicum inoculation and phosphorus (P) supplements. World Journal of Soil and Crop Sciences Research 1:1-9.

Tairo EV, Ndakidemi PA. 2014a. Macronutrients Uptake in Soybean as Affected by Bradyrhizobiumjaponicum Inoculation and Phosphorus (P) Supplements. American Journal of Plant Sciences 5:488-496.

Unkovich MJ,Pate JS. 2000. An appraisal of recent field measurements of symbiotic $\mathrm{N}_{2}$ fixation by annual legumes. Field Crops Research 65:211-28.

Walpola BC, Yoon MH. 2012. Prospectus of phosphate solubilizing microorganisms and phosphorus availability in agricultural soils: a review. African Journal of Microbiology Research 6:6600-6605.

Zeffa DM, Fantin LH, Koltun A, de Oliveira ALM, Nunes MPBA, Canteri MG, Goncalves LSA. 2020. Effects of plant growth-promoting rhizobacteria on co-inoculation with Bradyrhizobium in soybean crop: a meta-analysis of studies from 1987 to 2018. PeerJ 8:e7905 http://doi.org/10.7717/peerj.7905 
Original paper

DOI: $10.5937 / Z e m B i l j 2102056 S$

\section{Efekat inokulacije bradirizobijalnim i fosfosolubilizirajućim bakterijama na prinos i sastav semena soje}

Olivera Stajković-Srbinović ${ }^{1 *}$, Djordje Kuzmanović ${ }^{1}$, Nataša Rasulić ${ }^{1}$, Magdalena Knežević ${ }^{1}$, Vladan Ugrenović $^{1}$, Aneta Buntić ${ }^{1}$, Dušica Delić ${ }^{1}$

${ }^{1}$ Institut za zemljište, Teodora Drajzera 7, 11000 Beograd, Srbija

*Corresponding author: Olivera Stajković-Srbinović, oliverastajkovic@yahoo.com

\section{Izvod}

U poljskom eksperimentu je ispitan efekat koinokulacije sojevima Bradyrhizobium japonicum i Pseudomonas sp. na prinos semena i usvajanje nutrijenata kod soje (Glycine max L.). Rezultati su pokazali da inokulacija i koinokulacija semena soje sa B. japonicum i sojevima Pseudomonas sp. povećava prinos semena (od 63 do 134\%) i usvajanje N, P, K, Mg i Ca (kg ha-1) (od 65 do 167\%), u semenu u poređenju sa kontrolnim biljkama (neinokulisanim, neđuberenim biljkama). Koncentracija fosfora $\left(\mathrm{mg} \mathrm{kg}^{-1}\right)$ je bila povećana $\mathrm{u}$ inokulisanim i koinokulisanim tretmanima u poređenju sa kontrolom (do 15\%). Procenat N, kao i koncentracije K i Ca nisu se značajno razlikovale između tretmana i kontrole. Koncentracija Mg je bila povećana u koinokulisanim tretmanima i tretmanu sa mineralnim đubrivom. Usvajanje svih nutrijenata je bilo u pozitivnoj korelaciji sa prinosom semena, dok je koncentracija P jedina bila u pozitivnoj korelaciji sa prinosom semena. Studija je pokazala da koinokulacija bradirizobijalnim i fosfosolubilizirajućim bakterijama može da poveća prinos i usvajanje $\mathrm{N}$ i P kod semena soje.

Ključne reči: inokulacija, bradirizobije, Pseudomonas, azot, fosfor 